\title{
PARASITIC DISEASES OF THE PERCH (PERCA FLUVIATILIS) IN DETENTION RESERVOIRS OF THE MORAVA RIVER BASIN
}

\author{
Z. LUCKÝ, S. NAVRÁTIL
}

\author{
Department of Diseases of Poultry, Fish, Game and Bee, University of Veterinary Science \\ 61242 Brno
}

Received August 30, 1983

\begin{abstract}
Lucký Z., S. Navrátil: Parasitic Diseases of the Perch (Perca fluviatilis) in Detention Reservoirs of the Morava River Basin. Acta vet. Brno, 53, 1984: 81-90.

The state of health of fish was investigated from 1979 to 1982 in 9 detention reservoirs situated within the Morava river basin. Particular attention was paid to the perch which has been recognized a convenient species for drinking water reservoirs, inhibiting development of the carp family and not slurrying water in search for food.

The investigation showed that the perch was endangered by a number of parasitic diseases. A total of 15 parasitic species were determined, 8 among them were protozoa: Dermocystidium percae, Henneguya psorospermica, Chilodonella cyprini, Apiosoma campanulata, Apiosoma piscicola, Trichodina domerguei subsp. acuta, Trichodinella epizootica f. percarum, Trichophrya piscium. The strongest infections were caused by Trichodinella epizootica f. percarum and Trichophrya piscium.

Five species of parasitic helminths were determined: Proteocephalus percae, the plerocercoid of Triaenophorus nodulosus, the metacercaria of Tylodelphis clavata, Camallanus lacustris, and Acanthocephalus lucii. The decay of perch in the reservoir Hubenov was a consequence of proteocephalosis, plerocercoids, metacercariae and acanthocephala of the species named above which manifested distinct pathogenicity.

Parasitic arthropods were represented by two species: Ergasilus sieboldi on gills was frequent, Hydrozoetes lacustris occurred sporadically.

The extent of infestation in different reservoirs under study, the pathogenicity of the parasitic species determined in them, and the prophylactic measures proposed are discussed.
\end{abstract}

Protozoa, helminths, arthropods, extensity and intensity of infestation.

From 1979 to 1982, the state of health of fish was investigated in 9 detention reservoirs within the Morava river basin. Particular attention was paid to the perch which has been recognized a convenient species for drinking water reservoirs. The perch inhibits development of fish of the carp family, and does not rip the bottom and slurry water when attacking prey.

The detention reservoirs under study cover a comparatively extensive area. They are supplied by creeks and small rivers rich in trout, as depicted in the schematic map of the Morava river basin with the reservoirs, complemented by data about altitude and character of the reservoirs (see Fig. 1).

Four of the reservoirs investigated were either void of the perch (Bojkovice, Fryšták, Koryčany, Slušovice), or the number of perch fished was not sufficient to be evaluated within this study. 


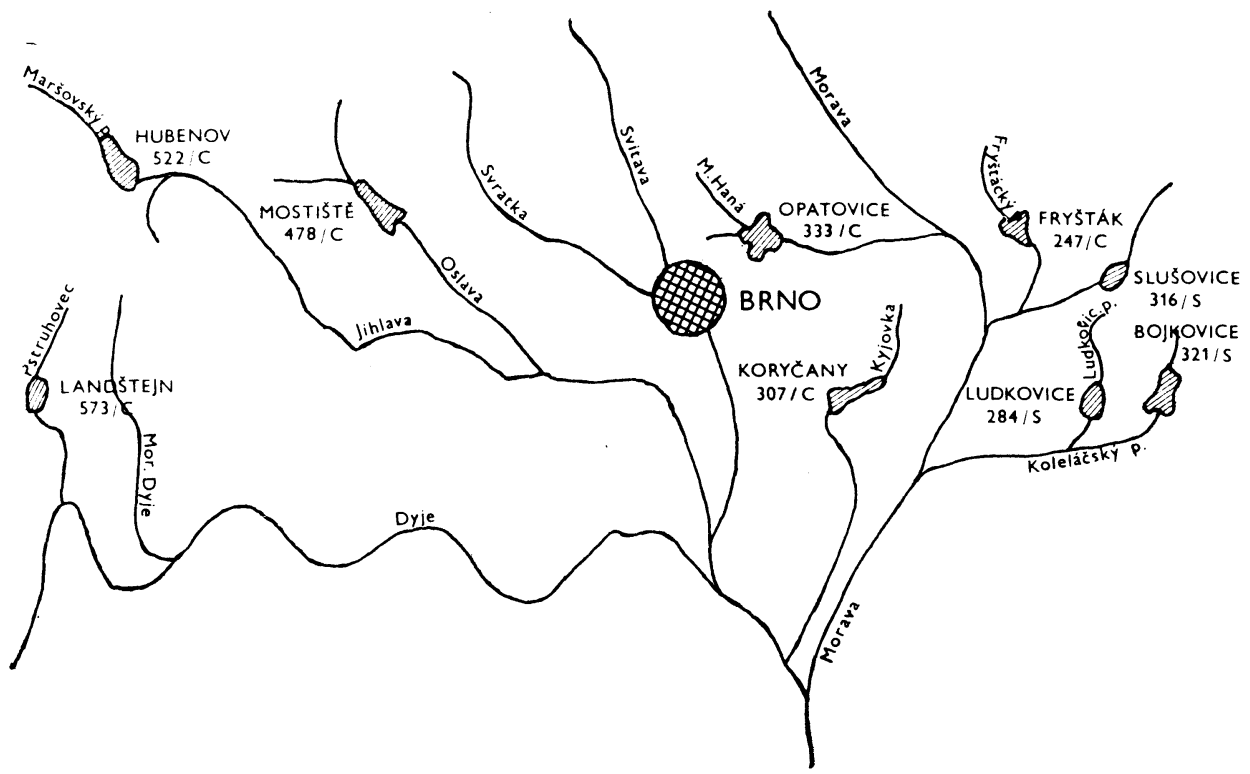

Materials and Methods

A total of 161 perch were examined in the rest of 5 reservoirs.

Samples of fish were collected by net or angle, and transported to laboratory in chopped ice. The length and weight of each fish were registered.

Examination of the samples was carried out within 24 hours after fishing. The state of health was classified on the ground of post-mortem examination and parasitological examination of organs.

The processing and diagnostic methods employed have been described by Lucký (1976) Dyk (1961) Bychowski et al. (1962) Ergens and Lom (1970) Lucký (1979).

\section{Results and Discussion}

Our investigation revealed that the perch was endangered by a number of parasitic diseases.

Table 1 shows a review of parasites of the perch we encountered in the 5 reservoirs investigated (Hubenov, Landštejn, Ludkovice, Mostiště, Opatovice). Included are data concerning the average extensity of infestation (calculated from the total of fish examined in each reservoir), the maximum intensity of infestation found in individual samples, and, the intensity of infestation in positive fish, presented either in absolute figures or as the number of parasites observed in the microscopic field at 30 fold magnification.

Among the 15 parasitic species determined, 8 species were protozoan: Dermocystidium percae, Henneguya psorospermica, Chilodonella cyprini, Apiosoma campanulata, Apiosoma piscicola, Trichodina domerguei subsp. acuta, Trichodinella epizootica f. percarum, and Trichophrya piscium.

The most spectacular pathogenic effect was caused by Trichophrya piscium in the resorvoir Hubenov. Beside a high mean and maximum extensity, the inten- 


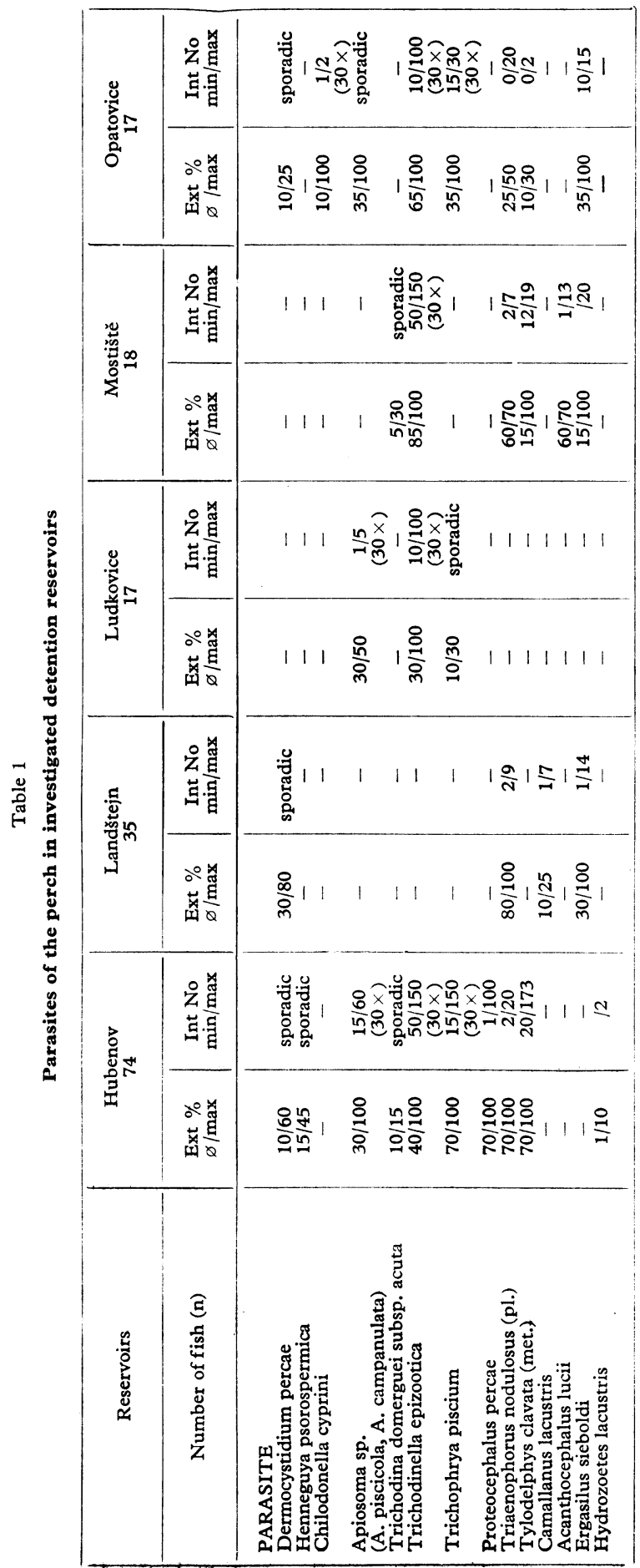


sity of infestation on gills was as massive as 150 parasites in one microscopic field. The consequence was suffocation of perch in this reservoir in July 1979.

The intense invasions by Trichodinella epizootica f. percarum in Hubenov, Ludkovice, Mostiště and Opatovice resulted in no major alterations of the state of health in perch. As for the rest of infestations by protozoa, they occurred in low intensity, though their extensity was comparatively high.

Five species of parasitic worms were determined: Proteocephalus percae, plerocercoids of Triaenophorus nodulosus, metacercariae of Tylodelphis clavata, Camallanus lacustris, and Acanthocephalus lucii. Pathogenic consequences were due to Proteocephalus percae in the first place, then to Triaenophorus nodulosus, Tylodelphis clavata, and Acanthocephalus lucii.

The tapeworm Proteocephalus percae was found only in Hubenov. The infestation was massive, amounting even several tens of worms within one intestine. The gut

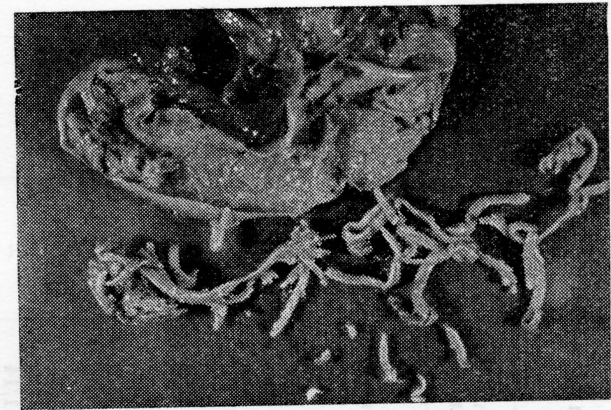

Fig. 2. The intestine of a perch invaded by the tapeworm Protocephalus percae. The gut is literally stuffed with the parasites, showing signs of heavy inflammation and its wall is thickened.

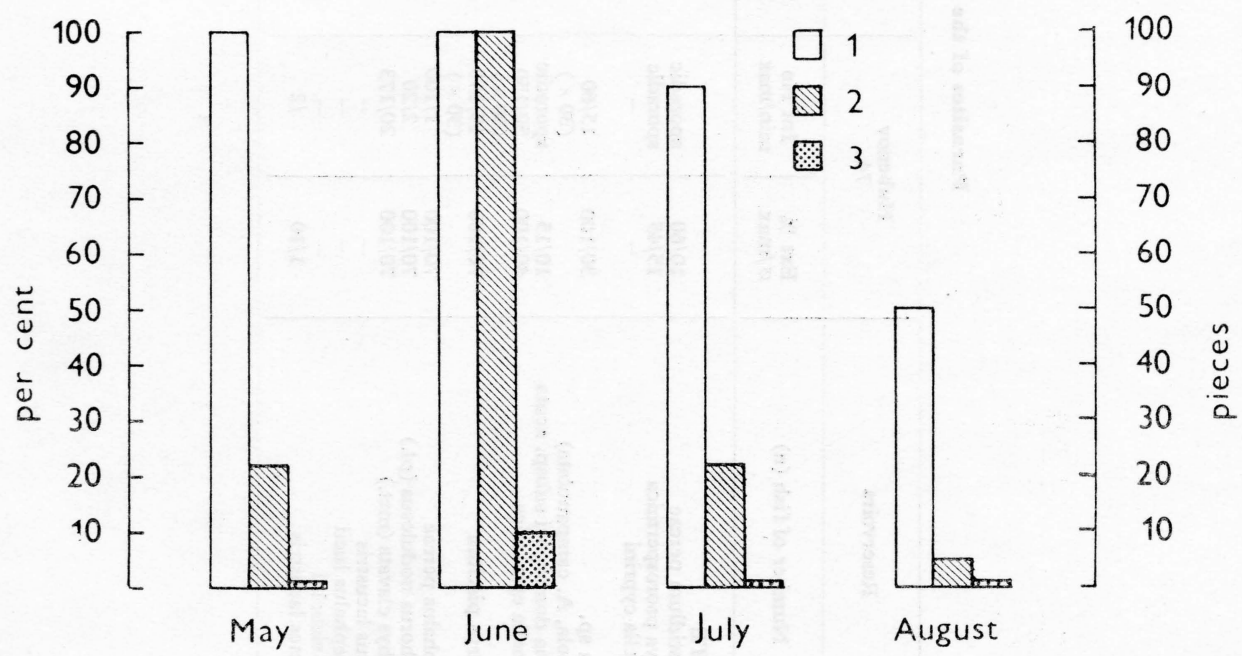

Graph 1. Seasonal dynamics of an outbreak of the tapeworm Proteocephalus percae infestation. 1 - extensity of infestation, 2 - maximum intensity of infestation, 3 - minimum intensity of infestation 
was literally stuffed with tapeworms, its epithelium alterated by inflammation, and its wall thickened (Fig. 2).

Graph 1 illustrates the dynamics of invasion by Proteocephalus percae. The disease attained its peak in June, most perch died in the course of that month. The progress of proteocephalosis was acute, several hundreds of perch perished within four weeks. The disease was associated with nervous disturbances - loss of balance, vehement jumping above the surface of water. Juvenile stages of the tapeworm were observed in August.

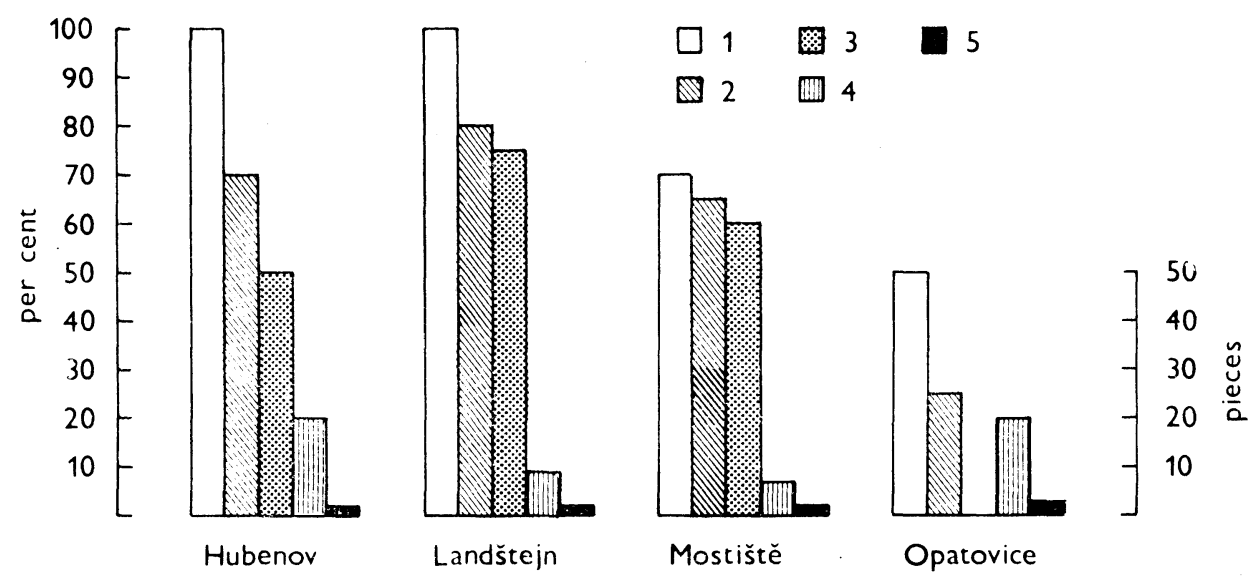

Graph 2. Extensity and intensity of an outbreak of Triaenophorus nodulosus plerocercoids in perch in the years 1979 to 1982

1 - maximum extensity of infestation

2 - mean extensity of infestation

3 - minimum extensity of infestation

4 - maximum intensity of infestation

5 - minimum intensity of infestation

Plerocercoids of Triaenophorus nodulosus caused severe disease in perch in the reservoirs Hubenov, Landštejn, Mostiště and Opatovice. Extensity and intensity of the infestation are demonstrated on Graph 2. Average extensity in different reservoirs ranged from 25 to 100 per cent, maximum extensity from 50 to 100 per cent, intensity varied from 2 to 20 . According to Kuperman (1973) the extent of pathologic alterations depends on the number of invasive parasites, their location in the host, and on the host organism itself. Penetration of plerocercoids into the liver tissue results in an exudative hepatitis. At this stage, inflammation of the liver in perch is never as severe as e. g. in rainbow trout. If the fish survives this stage, the parasite becomes encapsulated in the overgrowth of the connective tissue surrounding it. Formation of cysts is a typical host reaction to the lodged parasite, the cyst develops exclusively from host tissue. Encapsulation of Triaenophorus nodulosus has been studied in detail by Scheuring (1923) and Lopuchina (1966). According to them, the size of the cyst depends on the species of host, the age of the cyst, and its location. In smelt and perch the cyst is a thinwall formation inducing no remarkable overgrowth of connective tissue or symptoms of inflammation. Mature cysts often consist of a single fibrillar layer with a reticulate outer surface and a rich supply of blood vessels. By formation of such a cyst a kind of equilibrium can be established between parasite and host. Infestations 
in perch have therefore by far not such a devastating effect as e. g. in rainbow trout. The phenomenon probably accounts for the chronical course of the disease we observed. Kuperman (1973) reported that with natural invasion the number of plerocercoids was comparatively small: as a rule $1-2$, rarely $3-4$, exceptionally 10. In the ruff, Schulman (1961) registered 194 plerocercoids. During our own examination, we recorded up to 20 plerocercoids in one fish. Fig. 3 demonstrates liver of perch invaded by plerocercoids of the tapeworm Triaenophorus nodulosus. Fig. 4 presents histological findings from an infested liver. The liver tissue infiltrat-

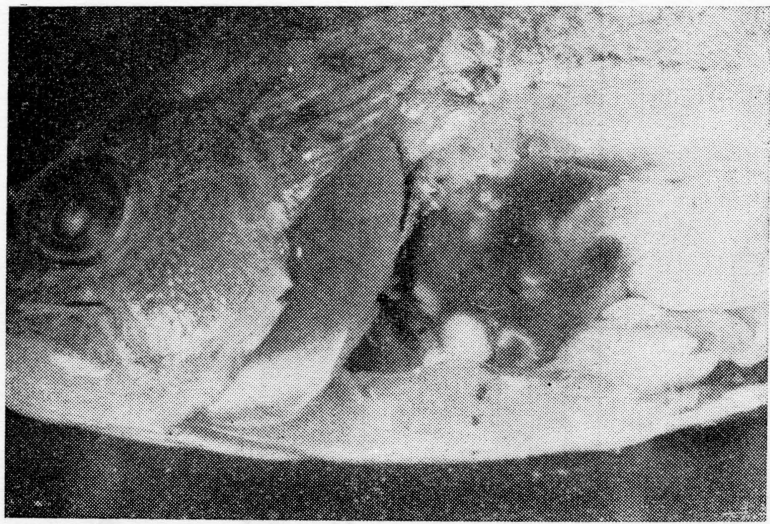

Fig. 3. The liver of a perch invaded by plerocercoids of the tapeworm Triaenophorus nodulosus.

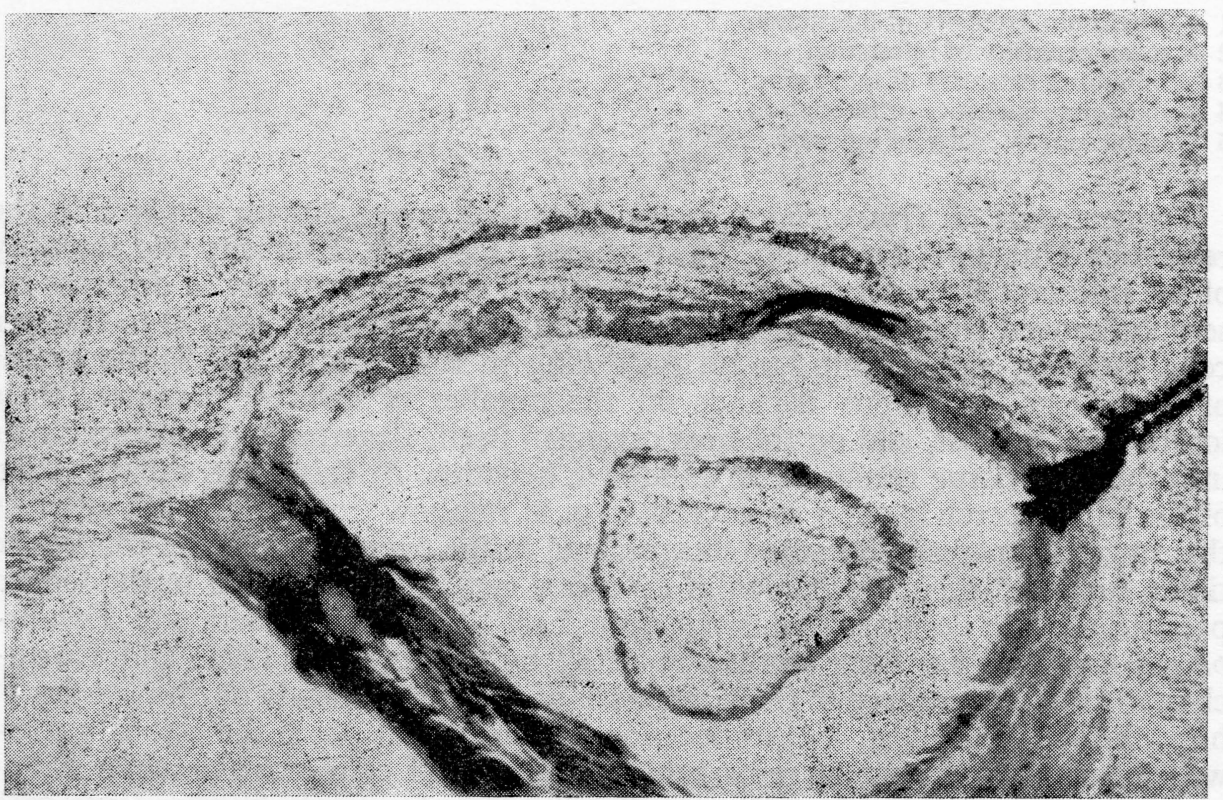

Fig. 4. Histological findings in the liver of a perch infested by Triaenophorus nodulosus. The liver tissue is infiltrated by cells, the wall of the cyst, and the centrally situated plerocercoid are visible (HE). 


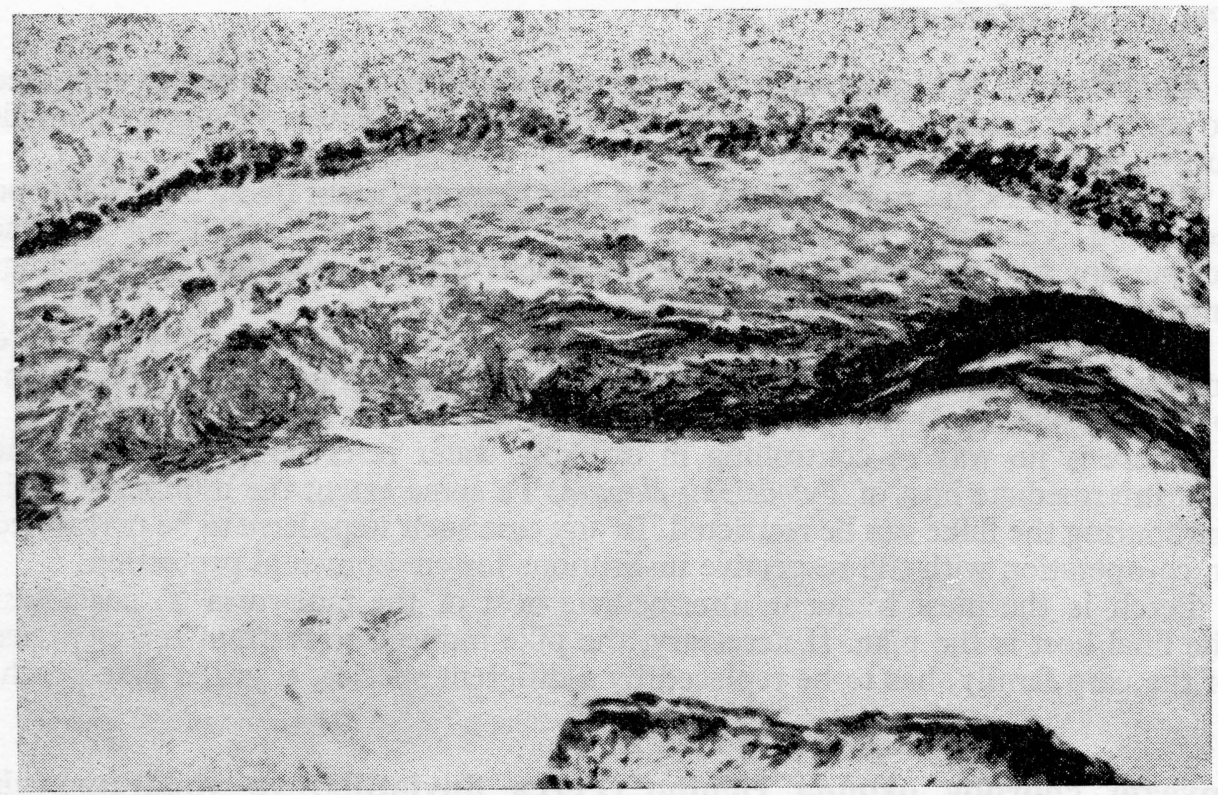

Fig. 5. Histological findings in the liver of a perch infested by Triaenophorus nodulosus (the same sample under higher magnification). For explanation, see Fig. 4. Photographs S. Navrátil.

ed by various cells typical of inflammatory reaction, the wall of the cyst, and the centrally situated plerocercoid can be seen.

According to Schulman and Rybak (1964) fish infection with T. nodulosus is significantly less in the more eutrophic waters containing rich planktonic material than in waters poor in plankton. This is accounted for by the fact that most of the planktophages have a preference not for copepods, but for cladocerans. This opinion finds support in our experience: while the disease occurred very frequently in oligotrophic drinking water reservoirs, it could be not proved in the eutrophic artificial detention lake Mušov, also in the Morava river basin, where 136 perches were examined in 1981 and 1982.

There was a intense infestation by metacercariae of Tylodelphis clavata in the reservoir of Hubenov. Its importance is not to be underestimated, since the hunting perch depends on its eyesight in the first place. The extensity was high, the intensity amounted $20-173$ metacercariae in one eye.

Camallanus lacustris was found in pyloric appendages of perch in the reservoir Landštejn. Extensity was low, intensity ranged from 1 to 7.

Acanthocephalus lucii exhibited pathogenic effect in form of local inflammation of intestinal epithelium in perch in the reservoir Mostiště. Extensity was medium, intensity varied form 1 to 13 .

From the two species of parasitic arthropods, Ergasilus sieboldi on the gills of perch was frequent in the reservoirs Landštejn, Mostiště and Opatovice. Average extensity ranged from 15 to 35 per cent, the maximum extensity was 100 per cent. Intensity varied from 1 to 20 parasites on one fish.

The mite Hydrozoetes lacustris was registered at Hubenov only. Extensity and intensity of the invasion were moderate, no pathogenic symptoms were recorded. 


\section{Practical inference}

Considering the hygiene of drinking water reservoirs, no chemotherapy supposed to control or eradicate diseases of fish is acceptable. Exclusively biological methods are to be employed.

The fish stock has to be kept on a level providing sufficient living food and good condition. Veterinary examination of fingerlings should be carried out in time to warrant an appropriate period for treatment prior to planting of fingerlings in reservoirs.

Massive incidence of protozoa and arthropoda can be considerably restricted in this way. Similar methods serve for limiting incidence of helminths with a complex life cycle.

There is no way of controlling in drinking water reservoirs molluscs - the first intermediate host of Tylodelphis clavata. To some extent the number of birds harbouring the fluke can be restricted. In any case such steps have to be performed in co-operation with the respective institutions for enviromental protection.

Perch is the most frequent intermediate host of the tapeworm T. nodulosus; the final host is the pike. If necessary, the pike induced to restrain some species of the carp family, has to be replaced by a different species, e. g. the pike-perch.

\section{Invazní choroby okouna říčního (Perca fluviatilis) ve vodárenských nádržích povodí Moravy}

V letech 1979-1982 byl sledován zdravotní stav ryb v 9 vodárenských nádržích ležících $\mathrm{v}$ povodí Moravy. Zvláštní pozornost byla věnována okounu říčnímu, který prokázal, že je vhodným druhem pro vodárenské nádrže, poněvadž tlumí rozvoj kaprovitých ryb a při lovu útočí na kořist přímo, bez rozrývání dna a zakalování vody.

Ve 4 sledovaných nádržích se okoun bud' nevyskytuje, nebo nebyl získán dostatečný počet kusủ těchto ryb pro zahrnutí získaných výsledků do této práce.

Sledování invazních chorob okouna ve zbývaiících 5 nádržích ukázalo, že jeho zdravotní stav ohrožují četné parazitózy.

Z 15 zjištěných druhů cizopasníků bylo 8 druhů prvoků: Dermocystidium percae, Henneguya psorospermica, Chilodonella cyprini, Apiosoma piscicola, Apiosoma campanulata, Trichodina domerguei subsp. acuta, Trichodinella epizootica f. percarum, Trichophrya piscium. Nejmasivnějších invazí dosáhly druhy Trichodinella epizootica f. percarum a Trichophrya piscium. Z cizopasných červů bylo zjištěno 5 druhů: Proteocephalus percae, plerocerkoid Triaenophorus nodulosus, metacerkarie Tylodelphis clavata, Camallanus lacustris a Acanthocephalus lucii. Hynutí okounư na nádrži Hubenov vyvolala proteocefalóza, výrazně patologicky se uplatnili plerocerkoidy, metacerkarie a vrtejši uvedených druhů. Ze dvou cizopasných členovců cizopasil na žábrách často Ergasilus sieboldi a ojediněle se vyskytl Hydrozoetes lacustris.

Práce se zabývá stupněm zamoření nádrží, patogenitou zjištěných cizopasníků a navrhuje reálná preventivní opatření. 


\section{Инвазионные болезни речного окуня (Perca fluviatilis) в водохранилищах бассейна реки Моравы}

С 1979 г. по 1982 г. исследовали состояние здоровья рыб в 9 водохранилищах, находящихся в водосборном бассейне реки Моравы. Особенное внимание уделяли окуню речному, который оказался видом весьма удобным для водохранилищ, так как он тормозит развитие карповидных и при лове атакует добычу прямо, не разрывая дна и не мутя воды.

В 4 исследованных водохранилищах окунь или не встречаегся, или не удалось получить достаточное количество этих рыб для возможного включения в нашу работу результатов исследования.

Исследование инвазионных болезней окуня в остальных 5 водохранилищах привело к заключению, что состояние здоровья этой рыбы находится под угрозой многочисленных паразитозов.

Из 15 обнаруженных видов паразитов 8 видов относились к простейшим: Dermocystidium percae, Henneguya psorospermica, Chilodonella cyprini, Apiosoma piscicola, Apiosoma campanulata, Trichodina domerguei subsp. acuta, Trichodinella epizootica f. percarum, Trichophrya piscium. Наиболее массивными оказались инвазии, вызванные видами Trichodinella epizootica f. percarum и Trichophrya piscium. Из паразитирующих червей было выявлено 5 видов: Proteocephalus percae, плероцеркоид Triaenophorus nodulosus, метацеркарии Tylodel,phis clavata, Camallanus lacustris и Acanthocephalus lucii. Гибель окуней в водохранилище Губенов была вызвана протеоцефаллезом, значительное патологическое влияние оказали плероцеркоиды, мегацеркарии и скребни вышеуказанных видов. Из двух паразитирующих членистоногих на жабрах часто встречался Ergasilus sieboldi, в одном случае был обнаружен Hydrozoetes lacustris.

Авторы в работе занимаются исследованием степени загрязнения водохранилищ, патогенности обнаруженных паразитов и они предлагают осуществимые мероприятия для предупреждения паразитозов.

\section{References}

BEREZANCEV, J. A.: Inkapsulacija bičinok parazitičeskich nematod i cestod v tkanjach pozvonočnych kak forma zaimootnošenija parazita i chozjaina. Autoreferat diss., Leningrad, 1964: 33 pp.

BYCHOWSKI et al: Opredělitěl parazitov presnovodnych ryb SSSR. Moskva - Leningrad 1962: $776 \mathrm{pp}$.

DOGEL, V. A.: Parazitarnye zabolevanija ryb. Leningrad, 1932: 151 pp.

DYK, V.: Choroby ryb. Praha, 1961: 000.

ERGENS, R. - LOM, J.: Pưvodci parazitárních nemocí ryb. Praha, 1970: 383 pp.

KUPERMAN, B. I.: Lentočnye červy roda Triaenophorus - Parazity ryb. Leningrad, 1973: $222 \mathrm{pp}$.

LOPUCHINA, A. M.: Vlijanie Triaenophorus nodulosus Pallas (Cestoda: Pseudophyllidae) na segoletkov radužnoj foreli. Dokl. Akad. Nauk SSSR, 131, 1, 1961: 244-247.

LOPUCHINA, A. M.: Vlijanie lentočnovo červa Triaenophorus nodulosus Pallas (Cestoda: Pseudophyllidae) na rost $\mathrm{i}$ upitannost' ladošskoe koryumki. Izvestia Všesoprzn Naučno-Issled. Inst. Ozern i Rechn. Rybn. Khoz., No. 54: 119-129.

LOPUCHINA, A. M.: Vlijanie zaraženija lentočnym červem Triaenophorus nodulosus (Pallas, 1760) (Cestoda: Pseudophyllidae) na organizm ryb. Avtoreferat diss., Leningrad: 33 pp.

LUCKÝ, Z.: Metodické návody k diagnostice nemocí ryb. Praha, 1976: 150 pp.

LUCKÝ, Z.: Veterinární péče $\mathrm{v}$ chovech ryb. Pardubice, 1979: 000. 
SCHEURING, L.: Studien an Fischparasiten. 1: Triaenophorus nodulosus (Pall.) Rud. und die durch ihn im Fischkörpen hervogerufenen pathologischen Veränderungun. Ztsch. Fischerei, No. 22, 1923: 93-204.

SCHULMAN, S. S. - RYBAK, V. F.: Itogi ekologo - parazitologičeskogo issledovanija ryb presnovodnych vodoemov karelii. Sb. K. prirodn. očagovosti parazitarn. i transmission. zabolevani v Karelii. Leningrad, 1964: 3-20. 